УДК 782.8

doi 10.17072/2219-3111-2021-4-25-27

Ссылка для цитирования: Randolph J. Comment: the Utility of «Celebrity» // Вестник Пермского университета. История. 2021. № 4(55). С. 25-27.

\title{
COMMENT: THE UTILITY OF «CELEBRITY»
}

\section{J. Randolph}

Department of History, University of Illinois Urbana-Champaign, Urbana, Illinois, 61801, USA

jwr@illinois.edu

ORCID: 0000-0001-8904-9617

Replying to the two contributions in this special issue, this commentary considers the work "celebrity" can do as a concept and topic of inquiry for historians of Russia. The author compares and contrasts "celebrity" (as an angle of vision) with investigations the formation of "public" and "private" life in $19^{\text {th }}$ century Russia. He underlines two uses of the concept: 1) as a reminder of continuities and instabilities that link modern forms of fame with pre-modern systems of reputation; and 2) as a marker of global forces that were pushing beyond nationalized, institutionalized frames of public and private life. The author returns to some earlier work he has done on Russian intellectual history, to consider how discussions of "celebrity" reframe what an older literature might describe as the "making of intelligentsia traditions." $\mathrm{He}$ also highlights several important conceptual contributions made by Konstantin Shneyder's historiographical analysis, and considers what conclusions can be drawn from Matthew Klopfenstein's reconstruction of the "operatic" death of Angiolina Bosio.

Key words: celebrity, intelligentsia, public, private, reputation, modernity.

For historians of Russia, what work can "celebrity" do? Konstantin Shneyder's thoughtful analysis starts our discussion by reminding us of two uses the concept has had for history as a whole. On the one hand, "celebrity" - defined most basically as personal judgments about people you do not know - inhabits and undermines the boundaries of "public" and "private" life (to name two other categories fiercely contested by contemporaries and historians alike). Where publicity imagines a judiciously transparent world - where all relevant knowledge is out in the open - celebrity conjures the existence of important, "behind-the-scenes" things the public only imperfectly see. Ironically, those are often the very things, which some might wish to be "private life"; yet celebrity represents the demand that these are precisely the things that can and will be widely ("publicly") known. When all this happens in a face-to-face world - to adopt Antoine Lilti's scheme - we might talk of this solely as matter of reputation, the banter of intimate circles. Yet when placed in the vastly faster, vastly more transcribed modern communications environment born in the $19^{\text {th }}$ century, such reputational controversies could rebound far beyond such circles, and also far beyond any neatly institutionalized sense of what is or should be public or private. In this sense, celebrity can also remind us that even as states and societies seek to order their existences in a host of local frames, global modernity is pushing outside them [Osterhammel, 2009].

In short, the analysis of celebrity invites historians to simultaneously investigate the existence and proper boundaries of "public" and "private" in modern life while also analyzing the ways in which that same modernity was working beyond them. The result is to reset a number of scholarly discussions. Whereas sometimes - post-Habermas - historians have gotten bogged down by the question of whether a public sphere had or had not formed here or there - as if this bus was going to come, and the only question was when - celebrity reminds us that modernity has many possible routes and destinations. It also, to my mind, raises the question of how this modern re-mediation of reputation really relates to the much older human worlds of gossip and secret-sharing. However uniquely modern the commercial, typographic, telegraphic and (ultimately) informatic technologies that broadcast this content, how pre-modern does our global village remain?

In the $19^{\text {th }}$ century, it will be recalled, Russian historians were quite concerned with all of these questions [Randolph, 2004]. One result was pathbreaking works on Russian intellectual history that anticipated the course of intellectual biography across the $20^{\text {th }}$ century more generally. Decades before 
Lytton Strachey's Eminent Victorians broke Victorian taboos about analyzing the personal lives of eminent people, scholars such as P. V. Annenkov, A. N. Pypin, P. N. Miliukov, and A. A. Kornilov began mining the personal archives of Russian thinkers in order to solidify their historical reputations [Strachey, 1918; Annenkov, 1857; Pypin, 1876; Miliukov, 1902; Kornilov, 1915]. As he wrote the first fundamental biography of Vissarion Belinsky, for example, Pypin despaired of reconstructing the great social critic's intellectual evolution on the basis of Belinsky's published writings. Belinsky's public utterances seemed riddled with inconsistencies and gaps, produced by some combination of cruel circumstances (censorship, poverty, the instability of Russia's press, etc.). The real legacy of this major Russian thinker, Pypin exclaimed to Annenkov, must somehow be sought "behind his articles and expressions" [Ukhmylova, 1951, p. 305]; and by behind Belinsky's public life Pypin meant in the records of his personal relations. Following in Annenkov's footsteps - and with Miliukov and Kornilov, among others, following in his - that is where Pypin sought the truth about Russian intellectual evolution in the first half of the $19^{\text {th }}$ century: in family archives that could illuminate, for outsiders, this intimate theater of history.

Before recent discussions of celebrity, we might be tempted to bracket this story off as an example of "the development of intelligentsia traditions": as a drama, in other words, that built off the activity of a few isolated circles and a few sympathetic historians determined to shore up their place in history. Konstantin Shneyder's repositioning of Russia's famous intellectual "circles" [kruzhki] as «площадками для квазипубличных дискуссий, в которых формировался отечественный феномен "селебрити" », however, helps us place this old story in a new comparative framework. It also, to my mind, helps us revise Lilti's definition of celebrity as being a phenomenon concerned primarily with «здесь и сейчас, чуждая всякой коммеморативности». On the one hand, though Руріn and Miliukov would no doubt flinch at the comparison and indeed were very concerned their work might vulgarize the memory of truly historical Russians - to what degree should attempts to historicize Russian thinkers be separated from the sort of mass opera fandom Matthew Klopfenstein documents in the Russian Empire already in the 1860s? (It seems important in this context to remember that Mikhail Bakunin, as a young man, drew a portrait of Hegel for his sisters, so that they could hang it on their wall.)

On the other hand, precisely because the publication of personal lives could not always occur “здесь и сейчас" (given both public and private sensibilities) the imperial Russian case reminds us that some forms of celebrity might take several decades - or even a few regime changes - to fully develop. Whereas (as Klopfenstein writes) a "female opera performer like [Angiolina] Bosio was uniquely positioned" to be produced as a celebrity in the emerging 'middlebrow' culture of her day, the same cannot be said of the men whose intimate history depended on the "private autonomy" represented by noble family archives (such as Belinsky, Nikolai Stankevich, and other "idealists of the 1830s"). As Klopfenstein shows, theater-goers, journalists, and their readers across the Empire responded to news of Bosio's death as to an extension of her public performances - indeed, as their own opportunity to respond operatically to their beloved opera-singer - rather than as to an event happening to a person they did not know. "As a prima donna", he writes, "Bosio embodied the ambiguous status of a figure who represented the ideals of art and was a commodified object of desire". Her reputation was open for aspersion, but also to further invention. Annenkov, Pypin, Miliukov, Kornilov and other intellectual biographers, meanwhile, faced decades of negotiations with both official censors and family members before they could get their intimate histories into print. Bosio's death was an instant cause célèbre; Belinsky's personal life, a cause commemorated and celebrated only slowly; but one that would, thanks in part to the search for revolutionary ancestors in the Soviet era, have a far longer celebrity than Bosio's.

Neither of these forms of celebrity could have existed without the growth of readers, reading, printing, and information circulation that globally transformed the communications environment of the second half of the $19^{\text {th }}$ century: thick journals, lithography, big books, big book sellers, and the commercial and transportation networks necessary to carry these wares out into the broader world. That said, it is important to note that this "communications revolution" [Behringer, 2006] makes older forms of intimacy more, not less active. One distinct virtue of the essays presented here is that by focusing on the early $19^{\text {th }}$ century - and by placing their explorations of celebrity within longer discussions of Russian public space - they allow us to explore the productive tensions of this era. Shneyder's 
essay helps us understand how new visions of celebrity did and did not build off of the "private autonomy" built around noble culture as part of its continued "Europeanization" under Catherine. Klopfenstein's contribution points to the use of these same new cultural forms to create new kinds of celebrity (and agency) among broader, non-noble publics, employing gender-specific forms and the possibilities of new media. Exploring the spatial as well as temporal boundaries of this celebrity (within the nineteenth century and beyond it, inside and outside Russia and Russian history) gives cultural historians lots to think about.

\section{References}

Annenkov, P.V (1857), Nikolai Vladimirovich Stankevich: Perepiska ego i biographiya [Nikolai Vladimirovich Stankevich: His Correspondence and Biography], Tipografiya Katkova, Moscow, Russia, $395 \mathrm{p}$.

Behringer, W. (2006), “«Communications Revolutions»: A Historiographical Concept”, German History, vol. 24, № 3, pp. 333-374.

Kornilov, A.A. (1915), Molodye gody Mikhaila Bakunina: Iz istorii russkogo romantizma [The Young Years of Mikhail Bakunin: From the History of Russian Romanticism], S. Sabashnikov, Moscow, Russia, 718 p.

Milyukov, P.N. (1902), "«Love» among the idealists of the thirties»: From the history of the Russian intelligentsia", in Sbornik statey [Collection of articles], Tipografiya A.E. Kolpinskogo, St. Petersburg, Russia, pp. 73-168.

Osterhammel, J. (2009), Die Verwandlung der Welt: Eine Geschichte des 19. Jahrhunderts, C.H. Beck, Munich, Germany, 1568 p.

Pypin, A.N. (1876), Belinskiy: ego zhizn' i perepiska [Belinsky: his life and correspondence], Vestnik Evropy, St. Petersburg, Russia, 314 p.

Randolph, J. (2004), "«That Historical Family»: The Bakunin Archive and the Intimate Theater of History in Imperial Russia, 1780-1925”, Russian Review, vol. 63, № 4, pp. 574-593.

Strachey, L. (1918), Eminent Victorians, G. P. Putnam's Sons, New York, USA, 351 p.

Ukhmylova, T. (1951), "Materials about Belinsky from the archive of A.N. Pypin", Literaturnoe nasledstvo, Vol. 57, pp. 303-318.

Дата поступления рукописи в редакичию 29.10.2021

\section{КОММЕНТАРИИ: УСЛУГИ «СЕЛЕБРИТИ»}

\section{Дюж. Рэндольф}

Иллинойсский университет в Урбане-Шампейне, 61801, США, Урбана, Иллинойс jwr@illinois.edu

ORCID: 0000-0001-8904-9617

Предлагаемые комментарии являются ответом на две статьи в данном выпуске и рассматривают возможности «селебрити» как предмета изучения экспертов. Автор сравнивает и противопоставляет категорию «знаменитости» исследованиям становления общественной и частной жизни в России ХІХ в. Он формулирует два основных варианта использования этого концепта: 1) как напоминание о преемственности и непрочности, которые связывают современное понятие славы с предшествующим понятием репутации; 2) как маркер глобальных сил, которые выходили за рамки национализированных, институционализированных границ общественной и частной жизни. Автор возвращается к некоторым более ранним работам по российской интеллектуальной истории для изучения вопроса о том, как дискуссии о «знаменитости» переосмысливают то, что в более ранней литературе можно было бы описать как «создание традиции интеллигенции». Автор выделяет несколько важных концептуальных положений, сделанных в историческом анализе Константином Шнейдером, и рассматривает, какие можно сделать выводы из реконструкции «оперной» смерти Анжиолины Бозио Мэттью Клопфенштейном.

Ключевые слова: «селебрити», интеллигенция, публичное, частное, репутация, модерность. 